UDC 72-03

doi: 10.31650/2519-4208-2020-20-221-228

\title{
ARCHITECTURE OF ODESSA SANATORIUMS (ON THE BORDER OF DISAPPEARANCE)
}

\author{
Morgun E. L., PhD in Architecture, Associate Professor of the Department of Design of the \\ Architectural Environment \\ Odessa State Academy of Civil Engineering and Architecture
}

\begin{abstract}
This publication is dedicated to the energy of Odessa sanatoriums, both disappeared and those on the verge of extinction. A typological classification of sanatoriums is given. It is proposed to divide the sanatoriums into four groups: by the time of their opening and from the point of view of the time of construction of buildings on their territories. According to the proposed classification, a change in the stylistics of the construction of sanatoriums is considered by examples. On the territory of one sanatorium there could be buildings of the period of historicism, monuments of constructivism, architecture of Soviet classicism of the 50s. last century and Soviet modernism. It was revealed that most of the buildings located on the territory of the sanatoriums are architectural monuments, listed in the register of Odessa architectural monuments. It was also revealed that the monuments are in emergency state or are being destroyed and already destroyed.

Conclusions on the development of sanatoriums are presented in the form of a table. As a result of writing the article, it became obvious that the architecture of Odessa sanatoriums was insufficiently studied, which makes it possible to conduct detailed research in a number of directions.
\end{abstract}

Key words: sanatoriums of Odessa, classification, style of building, historicism, constructivism, architecture of Soviet classicism, modernism.

\section{АРХІТЕКТУРА САНАТОРІЇВ ОДЕСИ (НА МЕЖІ ЗНИКНЕННЯ).}

Моргун О. Л., канд. архітектури, доцент кафедри дизайну архітектурного середовища Одеська державна академія будівництва і архітектури

Анотація: Ця публікація присвячена архітектурі одеських санаторіїв як зниклих, так і таких, що знаходяться на межі зникнення. Наводиться типологічна класифікація санаторіїв. Пропонується розділити санаторії на чотири групи: за часом їх відкриття і з точки зору часу зведення на їх територіях будівель. Згідно з запропонованою класифікацією, на прикладах розглянута зміна стилістики забудови санаторіїв. На території одного санаторію могли знаходитися будівлі періоду історизму, пам'ятники архітектури конструктивізму, архітектури радянського класицизму 50-х рр. минулого століття і радянського модернізму. Виявлено, що більшість будівель, що знаходяться на території санаторіїв, $є$ пам'ятниками архітектури, занесенеми в реєстр пам'ятників архітектури Одеси. Також виявлено, що пам'ятники архітектури знаходяться в аварійному стані або руйнуються чи зруйновані.

Висновки по забудові санаторіїв представлені у вигляді таблиці. В результаті написання статті стала очевидною недостатня вивченість архітектури одеських санаторіїв, що представляє можливість проведення детальних досліджень у ряді напрямів.

Ключові слова: санаторії Одеси, класифікація, стилістика забудови, історизм, конструктивізм, архітектура радянського класицизму, модернізм. 


\title{
АРХИТЕКТУРА САНАТОРИЕВ ОДЕССЫ (НА ГРАНИ ИСЧЕЗНОВЕНИЯ)
}

\author{
Моргун Е. Л., канд. архитектуры, доцент кафедры дизайна архитектурной среды \\ Одесская государственная академия строительства и архитектуры
}

\begin{abstract}
Аннотация: Публикация посвящена архитектуре одесских санаториев как исчезнувших, так и находящихся на грани исчезновения. Приводится типологическая классификация санаториев. Предлагается разделить санатории на четыре группы: по времени их открытия и с точки зрения времени возведения на их территориях зданий. Согласно предложенной классификации, на примерах рассмотрено изменение стилистики застройки санаториев. На территории одного санатория могли находиться постройки периода историзма, памятники архитектуры конструктивизма, архитектуры советского классицизма 50-х гг. прошлого века и советского модернизма. Выявлено, что большинство зданий, находящихся на территории санаториев, являются памятниками архитектуры, занесены в реестр памятников архитектуры Одессы. Также выявлено, что памятники архитектуры находятся в аварийном состоянии или разрушаются и разрушены. Выводы по застройке санаториев представлены в виде таблицы. В результате написания статьи стала очевидной недостаточная изученность архитектуры одесских санаториев, что представляет возможность проведения детальных исследований в ряде направлений.
\end{abstract}

Ключевые слова: санатории Одессы, классификация, стилистика застройки, историзм, конструктивизм, архитектура советского классицизма, модернизм.

Formulation of the problem. This publication raises the problem of preserving the architectural heritage in Odessa, this problem is closely related to the problem of the disappearance of Odessa sanatoriums, on the territory of which there are architectural monuments and buildings related to different periods of architecture development. Lands of sanatoriums, dispensaries, boarding houses and pioneer camps are being built up with elite cottages (sanatorium "Russia", named after Gorky), residential high-rise buildings (Gagarinskoye plateau), leased for 20 years, etc.

The aesthetic qualities of modern buildings are far from satisfactory, the buildings are strikingly monotonous. The author of this publication had a chance to hear the following statement: "Odessa has its own Manhattan", it was about the development of the Gagarin plateau in Arcadia (fig. 12). This characteristic of this area does not bear a positive connotation, especially for the inhabitants of Odessa. After all, the faceless Odessa "Manhattan" appeared on the site of sanatoriums, on the territory of which there were architectural monuments of the XIX-XX centuries. The once green hills are built up, covered with asphalt and paving slabs.

I would like to devote this small research to the architecture of Odessa sanatoriums, both disappeared and those on the verge of extinction. To show once again what damage is done to the architecture and recreational areas of Odessa. Indeed, on the territory of one sanatorium there could be buildings of the period of historicism, monuments of constructivism architecture, Soviet classicist architecture of the 50s. last century and Soviet modernism.

Analysis of recent research. The main stages of development and formation of architecture and building of the city were highlighted by V. I. Timofeenko, considering the architecture of public buildings, Timofeenko paid attention to the construction of resort complexes during the first five-year plans and the post-war period [1, 2]. In 2017, a study of local history by I.V. Arutyunova and A.V. Sherstobitov in the series "Outgoing Odessa. Sanatoriums "[3] was published. Materials about the history and fate of Odessa sanatoriums can be found on websites $[4,5]$.

Objectives of the work: to propose a classification of Odessa sanatoriums, consider examples, stages of development of the territory of sanatoriums, determine the style of buildings; show what a valuable layer of the history of Odessa architecture is on the verge of extinction. 
Resorts in Odessa appeared in the first half of the 19th century (in the 1830s on the Kuyalnitsky and Khadzhibey estuaries). At the end of the 20th century, over 20 sanatoriums and rest homes functioned in Odessa [3].

The sanatoriums can be classified as follows, by the time of their opening and from the point of view of the time of construction of buildings on their territories:

The first type is sanatoriums, opened in the 19th - early 20th centuries. (like sanatoriums from the begining), on the territory of which there are architectural monuments of various styles, and buildings erected in different periods.

The sanatoriums of the first type include the sanatorium. Pirogov on the Kuyalnik estuary. The history of the Kuyalnik resort began back in 1833, when, through the efforts of Dr. E. S. Andrievsky, the first baths appear. In the 40s. XIX century. the building of the hospital is being built, which is often used for other purposes (barracks, salt works) [6]. The revival of the resort began in 1868, by the beginning of the 90s. XIX century. its popularity is so great that in 1892. designed by architect N. K. Tolvinsky, the grandiose building of the Kuyalnitsky medical institution is being constructed (fig. 1) [7]. Eclectic in its architecture, the building of the limanmedical institution is in an extremely dilapidated state, but it is still valuable in terms of several value characteristics: historical, urban planning, aesthetic, utilitarian and functional [8].

The slopes of Zhevakhova Gora since the 40s. XIX century. Until 1917, they were built up with summer houses, buildings of private sanatoriums, hospitals, in the architecture of which historicism and modernism were reflected. The designs of these buildings were developed by architects V. A. Dombrovsky, F. A. Troupyansky.

The history of the resort continued in Soviet times. "In 1921. People's Commissar of Health of the RSFSR N. A. Semashko has visited Odessa and this year the development of resort construction in Odessa has started rapidly" [3, p. 6]. Already in 1928 in the Kuyalnitskiy resort (on the right side of the lake) the main building of the sanatorium named after Kaganovich (fig. 2), the project of which was developed by the architect F. A. Troupyansky.

Timofeenko noted the "dynamic composition of the masses" of the building [1, p. 73], the variety of forms characteristic of constructivist architecture. In the 50s. of the last century the resort was replenished with a new building - the building of a cinema - a concert hall. A cinema and concert hall was built on the site of a stage - "shells" ("shell" was built in the 1930s) on an island in the center of the lake. The theater building was designed in a solemn and triumphant style using "the best elements of the old classical architecture" [9]. In the late 1970s. at the Kuyalnitsky resort, large-scale construction is underway, 16-storey dormitory buildings and the building of the resort hall are being erected (fig. 4). The Kurhaus is one of the examples of the architecture of Soviet modernism, the image of the building is clearly inspired by the Villa Savoy Corbusier.

The second type is sanatoriums, opened in the 19th - first half of the 20th centuries. on the territory of former summer cottages, on the territory of which there are architectural monuments of various styles, and buildings erected in different periods.

The sanatoriums of the second type include the sanatoriums named after Chkalov and "Arcadia", located on French Boulevard, and the sanatorium named after Gorky (Fontanskaya road, 159). Buildings of the sanatorium $\mathrm{n}$. by Chkalov in the register of architectural monuments of Odessa designated at number 1043 as a complex of dachas consisting of 7 buildings.

The dachas were built in the 80s. XIX century. (in the style of historicism) and in 1910 according to the projects of architects F. V. Gonsiorovsky, P. U. Maple, A. B. Minkus. Chkalov's sanatorium was opened in the 1920s. XX century, a magnificent park united all buildings. A new dormitory building on the territory of the sanatorium appeared in 1937, the composition of the building is classical, central-axial symmetrical, the main entrance is highlighted by a projection and flanked by columns; everything is strict, practically devoid of decor, but in terms of masses and a small number of decor, it agrees well with the architecture of summer cottages of the 19th century. 


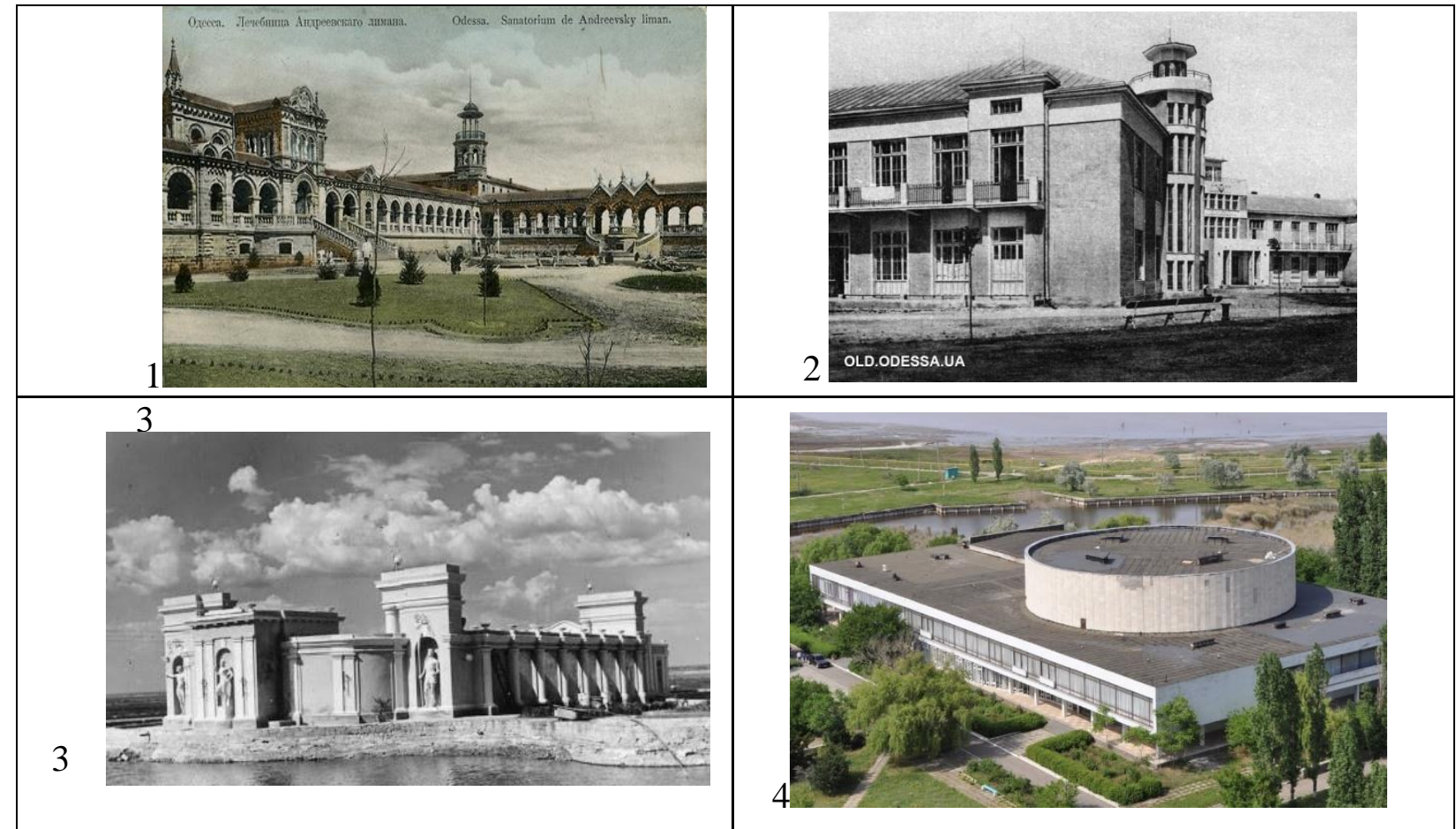

Sanatorium named after Pirogov on the Kuyalnik estuary:

Fig. 1. The building of the mud baths on the Kuyalnitsky estuary, 1890-1892,

arch. N. K. Tolvinsky 1 [11]

Fig. 2. The dormitory building of the Kaganovich sanatorium (on the territory of the modern Pirogov sanatorium, the building has not survived), 1928 (Source: http://viknaodessa.od.ua/oldphoto/?kuyalnik_sanatorij_im_kaganovicha)

Fig. 3. Cinema and concert hall, photo of the 50s. XX century (the building has not survived) [9] (Source: http://viknaodessa.od.ua/old-photo/?kuyalnik_sanatorij_im_kaganovicha)

Fig. 4/ Palace of Culture of the sanatorium, 1979, architect A. G. Ryzhkov, engineer

I. Ya. Sverdlov, KievZSRPISED (photo - electronic resources)

In the 1950s. in the park there were sculptures made in the spirit of socialist realism (destroyed by vandals). In the 60s. of the last century, an 8-storey dormitory building and a dining room building were built, the style of which is defined as functionalism.

Sanatorium "Arcadia" is also located on the territory of summer cottages built in the late 19th - early 20th centuries: cottages of Paraskeva, Mavrokordato, schools for the blind, includes the territory of the City Sanatorium. Unfortunately, only Paraskeva's dacha and the fence (18911892, architect P. U. Klein) are listed under number 1034 in the register of architectural monuments. The cozy, shady park of the sanatorium has always attracted attention, and, of course, changed, because it was required to combine the territory of summer cottages into a single complex. These changes were not global, the system of entrances to the territory, the main viewpoints on the buildings of summer cottages (dormitories and medical buildings) were taken into account. In the 50s of the last century, sculptural compositions "Swan Lake", "The Tale of Tsar Saltan", sculptures of athletes in the spirit of socialist realism, etc. appeared on the territory of the sanatorium park, which did not spoil the old park at all. Part of the territory of sanatoriums. Chkalova and "Arcadia" in recent decades have been alienated for residential elite development.

In the newspaper "Chernomorskaya Kommuna" dated July 21, 1934. a note was posted: "At the dacha of the former sugar tycoon Brodskaya (fig. 5) at the 16th station of the Bolshoi Fontan, an all-Ukrainian sanatorium for educators with 300 beds was arranged" [10]. It was about the sanatorium. Gorky, which can be attributed to the third type - sanatoriums, opened in the 2030s. XX century, on the territory of which there are architectural monuments of various styles, and buildings erected in different periods. The buildings of the sanatorium are located in the park, 
which has the status of a park-monument of landscape gardening art of local importance. To the right of the entrance is the building of the house of culture (club) of the sanatorium, built in 1952 by the architect G. V. Topuza. The building was described in detail by V. I. Timofeenko [2], but I would like to draw your attention to some points. The open area of the summer theater adjoins the house of culture, both objects are functionally united into a single whole. Embossed ornamental motifs cover the architectural details of the club's façade. Both in the ornaments and in the decorative elements that refer to the Baroque architecture, the national component is clearly expressed. The architecture of the building reflects the spirit and mood of the eras, but, unfortunately, is not included in the list of architectural monuments of Odessa.

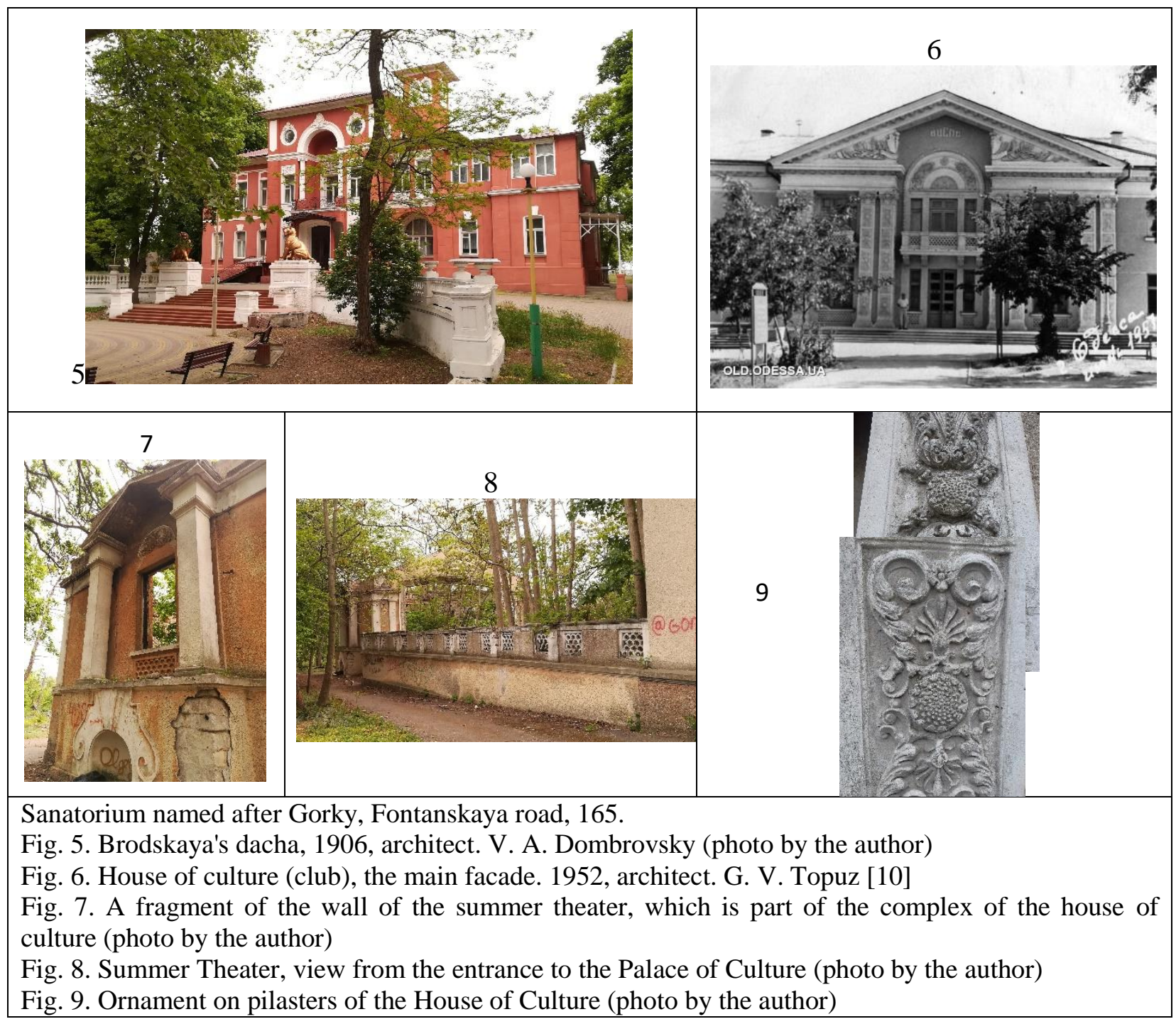

However, in Odessa, even the listed architectural monuments are not protected from destruction. An example of this is the building of the sanatorium "Russia", which can also be attributed to the third type of sanatoriums. The sanatorium was built in the 30s. of the last century on the "place of Anatra dachas, with the preservation of some buildings" [3]. At number 1040 in the register of architectural monuments of Odessa is a complex of buildings of the sanatorium "Russia", consisting of: an administrative building, 1935-1939, architect. F. Troupyansky; dormitory, 1935-1939, architect. M. A. Katz and M. A. Schlifer. In 2011, the city authorities signed a verdict to the sanatorium "Russia", giving its land to a developer for 20 years. The city has lost its architectural monuments of the 1930s, which are already few in the city, and a magnificent green area. 
Sanatorium "Ukraine" was built in 1935-1937. designed by architect I. O. Grodsky. Under the increased attention to the architecture of the Soviet period, the buildings of the sanatorium, built in the 70s of the last century in the style of the so-called Soviet modernism were of interest. The composition of the administrative building of the sanatorium "Ukraine" (1976) was built on a combination of two prismatic volumes - vertical and horizontal, but with a different interpretation of the facades. The horizontal 3-storey prismatic volume is divided vertically by strips of glazing and panels, adjacent to it is a transparent staircase prism. The buildings were demolished, and the sanatoriums themselves do not exist.

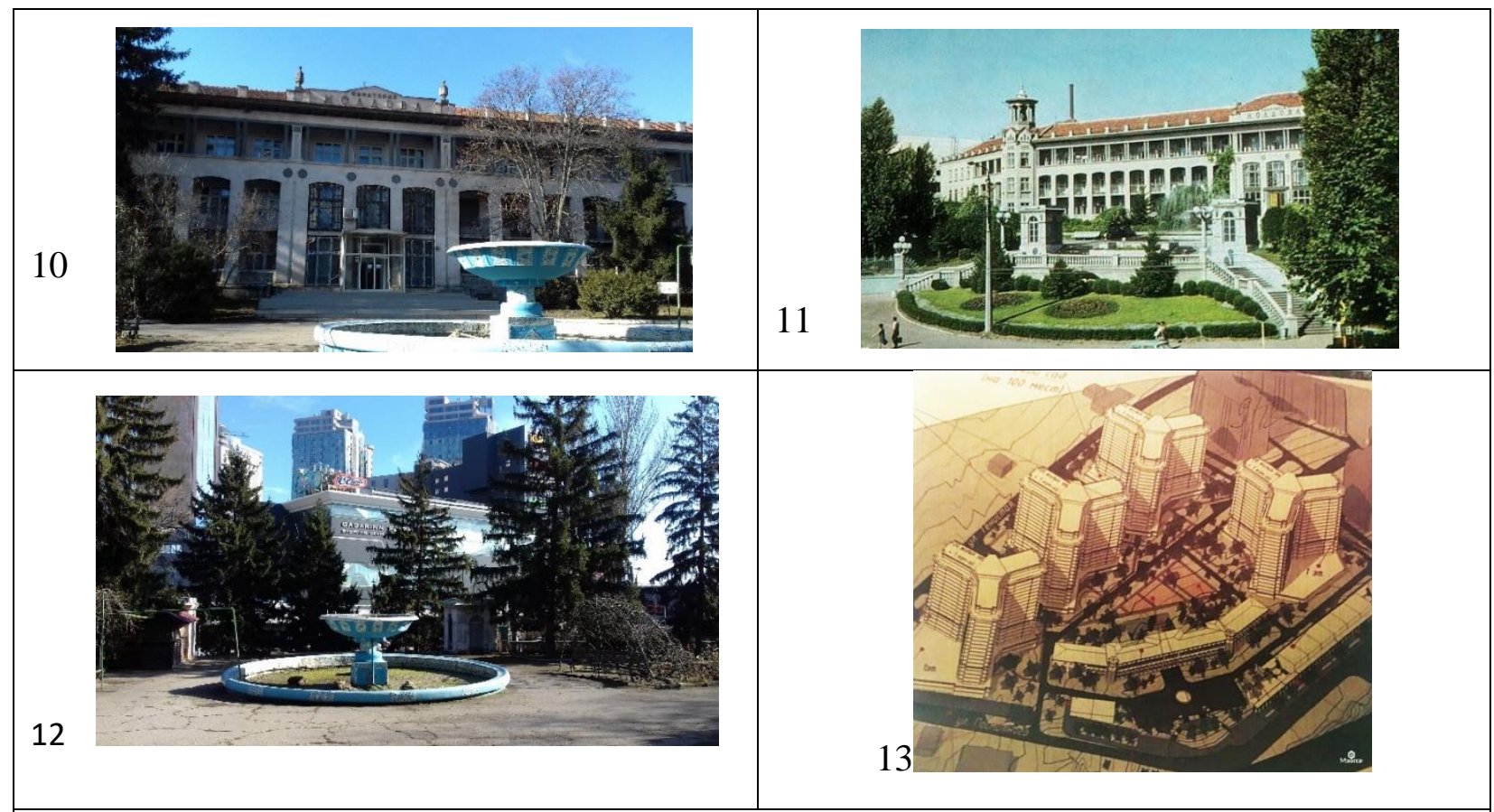

Sanatorium "Moldova", dormitory, 1955-1956

architects V. F. Smirnov, B. I. Shimkov, I. O. Grodsky

Fig. 10. Fragment of the central part of the facade (photo by the author)

Fig.11. Main building (postcard from the 1960s)

Fig.12. View of the Odessa "Manhattan" from the park of the sanatorium "Moldova" (photo by the author)

Fig. 13. Project for the development of the sanatorium territory with the next "cadors" (https://monitorodessa.com/gradostroitelstvo/zdravnicu-za-10-mln-sanatorij-molcards dova-vystavili-na-prodazhu /)

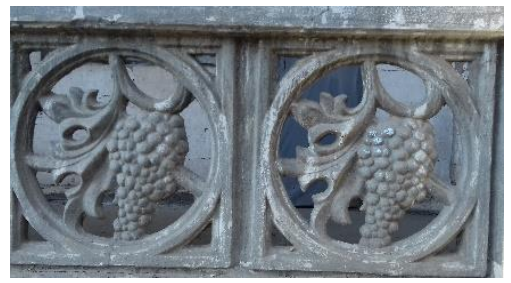

The fourth type is sanatoriums, opened in the 50s. XX century, on the territory of which there are buildings erected in different periods. The first building of the sanatorium "Moldova" was put into operation in 1955 (fig. 10, 11). "The picturesque relief is used quite successfully. The building is located on the top of a hill and dormitories rushed towards the sea. In the plan, a huge rectangular massif protrudes forward, and two buildings adjoin it at an angle, like the wings of a giant bird, " as V. I. Timofeenko wrote [1, p. 101]. The building successfully combined the neoclassical style characteristic of the Soviet architecture of this period with the forms and ornamental motifs inherent in Moldovan architecture. In 1977, a canteen club was built on the territory of the sanatorium (architect A. L. Goldenberg), construction continued in 1985 and 1989.

Conclusions: presented in the following table. The theme of the architecture of resorts and sanatoriums in Odessa can be researched as an independent topic, or included in research, for example, the architecture of Soviet modernism in Odessa. 


\begin{tabular}{|c|c|c|c|}
\hline Sanatorium & $\begin{array}{l}\text { Years of construction of } \\
\text { buildings }\end{array}$ & $\begin{array}{l}\text { Style of } \\
\text { buildings }\end{array}$ & Notes \\
\hline $\begin{array}{l}\text { Clinical sanatorium } \\
\text { named after Pirogov on } \\
\text { the Kuyalnitsky estuary }\end{array}$ & $\begin{array}{l}1890-1892 \\
\text { The first decades of the } \\
\text { XX } \\
1920-1930 \mathrm{~s} \\
1950 \mathrm{~s} \\
1970 \mathrm{~s}\end{array}$ & $\begin{array}{l}\text { Historicism } \\
\text { Modern } \\
\text { Constructivism } \\
\text { Soviet classics } \\
\text { Soviet } \\
\text { modernism }\end{array}$ & $\begin{array}{l}\text { Buildings built in the second half of } \\
\text { the 19th - early 20th century are in } \\
\text { disrepair, rebuilt, and are not used } \\
\text { for their intended purpose. } \\
\text { Buildings built in the } 30-50 \text { s XX } \\
\text { century - destroyed. } \\
\text { The dormitory buildings (1970s) and } \\
\text { the Kurhaus are partially exploited. }\end{array}$ \\
\hline $\begin{array}{l}\text { Sanatorium named by } \\
\text { Chkalov }\end{array}$ & $\begin{array}{l}\text { Second half of the 19th } \\
\text { century, early 20th century } \\
1937 \\
1960 \text { s }\end{array}$ & $\begin{array}{l}\text { Historicism } \\
\text { The transition } \\
\text { from } \\
\text { constructivism } \\
\text { to the classical } \\
\text { direction } \\
\text { Functionalism }\end{array}$ & $\begin{array}{l}\text { The buildings built in the second half } \\
\text { of the XIX - early XX are in a } \\
\text { dilapidated and disrepairment } \\
\text { condition, rebuilt, the Orangerie is } \\
\text { ruined. } \\
\text { The park is a monument of } \\
\text { gardening art. } \\
\text { Part of the territory is alienated for } \\
\text { residential development }\end{array}$ \\
\hline Sanatorium "Arcadia" & $\begin{array}{l}\text { Second half of the 19th } \\
\text { century, early } 20 \text { th century } \\
1950 \mathrm{~s}\end{array}$ & $\begin{array}{l}\text { Historicism } \\
\text { Modern }\end{array}$ & $\begin{array}{l}\text { Buildings built in the second half of } \\
\text { the XIX - early XX are in } \\
\text { dilapidated and disrepair, rebuilt., } \\
\text { Lost architectural details. } \\
\text { Part of the territory is alienated for } \\
\text { residential development }\end{array}$ \\
\hline $\begin{array}{l}\text { Sanatorium named after } \\
\text { Gorky }\end{array}$ & $\begin{array}{l}\text { Early XX century } \\
1950 \mathrm{~s} \\
1970 \mathrm{~s}\end{array}$ & $\begin{array}{l}\text { The transition } \\
\text { from historicism } \\
\text { to modernism } \\
\text { Soviet classics } \\
\text { with a } \\
\text { pronounced } \\
\text { national } \\
\text { component } \\
\text { Functionalism }\end{array}$ & $\begin{array}{l}\text { The buildings are being exploited. } \\
\text { Some of the buildings are in a } \\
\text { dilapidated state, architectural details } \\
\text { and fragments are lost. } \\
\text { Park-park is a monument of } \\
\text { landscape gardening art. } \\
\text { Part of the territory has been } \\
\text { alienated for the development of } \\
\text { elite cottages }\end{array}$ \\
\hline Sanatorium "Russia" & $\begin{array}{l}\text { 1930s } \\
1950 \mathrm{~s} \\
1960-1970 \mathrm{~s} .\end{array}$ & $\begin{array}{l}\text { Constructivism } \\
\text { Soviet classics } \\
\text { Functionalism } \\
\text { Modernism }\end{array}$ & $\begin{array}{l}\text { The territory of the sanatorium is } \\
\text { built up with elite cottages, high-rise } \\
\text { residential buildings } \\
\text { The sanatorium does not exist }\end{array}$ \\
\hline Sanatorium "Ukraine" & $\begin{array}{l}\text { 1930s, 1950-? } \\
1960-1970 \mathrm{~s}\end{array}$ & $\begin{array}{l}\text { Soviet classics } \\
\text { Modernism }\end{array}$ & $\begin{array}{l}\text { The territory of the sanatorium is } \\
\text { intended for construction. The } \\
\text { sanatorium does not exist }\end{array}$ \\
\hline Sanatorium "Moldova" & $\begin{array}{l}1950 \mathrm{~s} \\
1970-1980 \mathrm{~s}\end{array}$ & $\begin{array}{l}\text { Soviet classics } \\
\text { with a } \\
\text { pronounced } \\
\text { national } \\
\text { component } \\
\text { Functionalism? }\end{array}$ & $\begin{array}{l}\text { The building was built in the } 1950 \text { s. } \\
\text { is in disrepair. The territory of the } \\
\text { sanatorium is intended for the } \\
\text { construction of high-rise residential } \\
\text { buildings (fig. 13) }\end{array}$ \\
\hline
\end{tabular}




\section{LITERATURE}

1. Timofeenko V.I. Odessa: arhitekturno -istoricheskij ocherk. - K.: Budivelnik, 1983. - 160s.

2. Timofiyenko V.I Vidrodzhennya Odesi: Arhitektura povoyennogo desyatirichchya. - K.: Muzichna Ukrayina, 2006. - 484 s., il.

3. Arutyunova I.V., Sherstobitov V.V. Uhodyashaya Odessa (sanatorii). - Odessa, iz-vo KP OGT, 2017. - 113s.

4. Prodazha sanatoriya "Moldova" v Odesse [Elektronnij resurs]// uc.od.ua $>$ Novosti $>$ Urbanistika.

5. Strannye torgi po prodazhe odesskogo sanatoriya [Elektronnij resurs] // dumskaya.net $>$ news $>$ strannye-torgi-po-prodazhe-ode...

6. Herligi Patriciya. Odessa. Istoriya.1794-1914. -Odessa: Izd.-vo "Optimum”, 2007. - 576s.

7. Odessa 1794-1894: K 100-letiyu goroda. - Odessa : tipografiya A. Shulce. - 1895.

8. Morgun O.L., Gudzenko A.I. Limanno -lechebnoe zavedenie na Kuyalnickom limane// Problemy teorii i istorii arhitektury Ukrainy: sbornik nauchnyh trudov. - 2008. - Vyp. 8. - s.1015.

9. Sovetskaya arhitektura: ot dvorcov k korobkam [Elektronnyj resurs] - rezhim dostupa : http://propaganda-journal.net/9458.html

10. Sanatorij im.Gorkogo (1944-1991): Staraya Odessa v fotografiyah [Elektronnyj resurs] rezhim dostupa: http://viknaodessa.od.ua/old-photo/?sanatorij-gorkogo-1944-1991

11. Odessa na staryh otkrytkah: [kniga-albom] / avt.-sost. A.A. Drozdovskij. - Odessa: MChP “Even”,2006 - 416s.:ill. 